\title{
Status of lymphatic filariasis in Afikpo North L.G.A., Ebonyi State, Nigeria
}

\author{
Dr. Ngele K. K.
}

Biology/Microbiology/Biotechnology Department Federal University, Ndufu-Alike Ikwo, Abakaliki, Ebonyi State, Nigeria.

\begin{abstract}
The status of lymphatic filariasis in Afikpo North L.G.A., Ebonyi State, Nigeria was investigated among seven hundred and eighty one (781) subjects from thirty (30) villages, using the following Parasitological methods; the Wet Smear preparation, the Knott's concentration Technique and the Immunochromatographic Card Test (ICT). From the study, the following prevalence rates of Wuchereria bancrofti were obtained, wet smear preparation $(1.66 \%)$, the knott's concentration technique (5.38\%) and the ICT method (21.13\%). Subjects within the age group 58-62 years had the highest prevalence of $43.48 \%$, using the ICT method. Males were more infected $85(21.85 \%)$ than female $80(20.41 \%)$. There was no statistically significant difference in the prevalence of infection by gender using ICT cards $(P>0.05)$ at 2 tailed difference of .780. With the Knott's concentration technique, subjects within 58 - 62 years had the highest prevalence of $26.09 \%$. Males were also more infected $24(6.16 \%)$ than females $18(4.59 \%)$. The prevalence of hydrocoele was found to be $8.23 \%$. Hydrocoele was more frequent among older people of 53 years and above than the younger ones below the age of 27 years. The prevalence of lymphoedema was $8.88 \%$. Males were more affected with prevalence rate of $5.55 \%$ than females $(3.33 \%)$.
\end{abstract}

Keywords - Lymphoedema, Filariasis, Hydrocoele, Wuchereria bancrofti and Knott's concentration technique.

\section{INTRODUCTION}

More than 100 million individuals worldwide are estimated to suffer from lymphatic filariasis (LF) caused by infection with the mosquito-borne filarial nematode Wuchereria bancrofti (WHO, 1994). The infection induces sub-clinical abnormalities in the lymphatic system, which ultimately may result into the development of the overt clinical manifestations such as lymphoedema, elephantiasis, or hydrocoele (Ottesen, 1994; WHO, 1994). Lymphatic filariasis has been identified as the second leading cause of permanent and long -term disability and a major contributor to poverty in the world (Ottesen, 1994, WHO, 2003).
In Africa, lymphatic filariasis is caused by Wuchereria bancrofti and it is mainly transmitted to man through the bites of female Anopheles mosquito. Humans are the definitive hosts for Wuchereria bancrofti. There is no animal reservoir (Ottesen et al., 1997). Other species of filarial worms that may be associated with lymphatic filariasis are Brugia malayi and Brugia timori (WHO, 1994). The most important vectors for the transmission of W. bancrofti infection are Anopheles gambiae sensu stricto, anopheles funestus, Culex quinquefasciatus, Aedes polynessiensis, Aedes scapularis, Aedes pseudoscutelaris and Mansonia uniformis (Service, 1979; Hunter et al., 1976; Cheesbrough, 2002).

\section{AIMS AND OBJECTIVES}

The aims and objectives of the study include among others;

1. To establish the prevalence of lymphatic filariasis in the study area

2. To determine the influence of age and gender on the distribution of lymphatic filariasis (LF)

3. To determine the morbidity levels of lymphatic filariasis in the study area using clinical signs

\section{MATERIALS AND METHODS}

\section{THE STUDY AREA}

The study was carried out in 30 villages in Afikpo North Local Government Area of Ebonyi State, Nigeria. The villages are Ezi Egwu, Amangwu, Amasiri, Unwana, Akpoha, Ezinnali, Ibii, Amaechara, Mgbom, Amangballa, Amaobolobo, Amauzu, Ukpa, Amachi, Ngodo and Enohia Nkalu. Others include Kpogirikpo, Amaorie, Amaikpo, Enohia Itim, Amaukwu, Amankwo, Ugwuegu, Oti-village, Ogudu Amuku, Itim Ukwu, Ezi Nwachi, Amaizu, Amoha, and Amuro. Afikpo is located between latitudes $5^{\circ} 4^{\prime}$ and $6^{\circ} 3^{\prime} \mathrm{N}$ and longitudes $7^{0} 5^{\prime} \mathrm{E}$ and $7^{0} 55 \mathrm{E}$. There are two main seasons in this area, that is rainy season which is between April - October and dry season which lasts between November - March. The annual rainfall is about $160 \mathrm{~mm}-$ $220 \mathrm{~mm}$ with maximum precipitation occurring between July and September. The temperature ranges between $23.4^{\circ} \mathrm{c}$ 
and $29.9^{\circ} \mathrm{c}$. The relative humidity is between $60-80 \%$ (Iloeje, 1981; Federal Ministry of Aviation and Metrological Services 2000, NPC, 2006). Afikpo is bounded in the North by Ohaozara L.G.A. of Ebonyi State. By the East by Afikpo South L.G.A., in the South by Cross River State and also in the West by Abia State (Iloeje, 1981; NPC, 2006).

According to the 2006 National Population Census, the population of Afikpo people is about 672,000 persons. The area is hilly with undulating plains. The people are predominantly farmers producing rice, cassava, yam, vegetables, palm oil, coco yam, etc. They are also fishermen, hunters and a good number of them deal on timbers. These outdoor activities predispose them to mosquito bites, which transmits the microfilariae of $W$. bancrofti, the causative agent of lymphatic filariasis. Afikpo people have nucleated settlements. Most of the houses have mud walls and thatched roofs. The waste water from the households helps to create breeding sites for the mosquito vectors. Some houses are also not protected with mosquito nets, so as to disallow the entry of insects especially mosquitoes.

There are different bodies of water in the study area which include: Ndibe beach, Unwana beach, Iyi Enohia, Iyi Unwana, Ozizza beach, Akpoha River and their subsidiaries. These bodies of water, together with the typical forest vegetation and swampy areas for rice farming, timber lumbering, fishing, palm wine tapping etc, constitute an enabling environment which can serve as potential breeding sites for the mosquito vectors

\section{MOBILIZATION OF THE VILLAGERS/ETHICAL CONSIDERATION}

Ethical approval before the commencement of the study was sought from the director of public health in the State Ministry of Health. The chairman of the LGA and the elders of the communities were met and briefed on the importance and the rationale of the study, who then passed the information to the members of their villages. Some indigenes of the villages were recruited to help in reaching out to their people, for convenience purposes. The health centers in the various villages were used as a rallying point for the volunteer members (subjects) of the different villages to reduce the inconvenience of having to move from house to house with all the equipment/materials needed for the investigation and to give everyone an equal chance of being attended to. After the awareness and mobilization of the people, consent forms were distributed to everybody in the communities. Those that gave their consents were the examined.

\section{STUDY POPULATION}

The study population for the clinical and parasitological examinations included subjects between the ages of 18 years and above both male and females who presented themselves for examination at the medical centers to check for the physical signs of the disease such as hydrocoele and lymphoedema of the arms, legs, genital organs, breast etc and who had lived in that community for at least ten years. The sample size is 798 persons.

\section{CLINICAL EXAMINATION OF PARTICIPANTS}

Participants who came to the medical centers in response to the announcements were first of all documented, their demographic data such as name, age, occupation and duration of stay in the locality were obtained through the completion of questionnaire that were administered to them. They were made to undergo clinical examinations by the residents' clinicians in the health centers for the evidence of lymphatic filariasis infections among others. Such clinical manifestations like genital enlargement (hydrocoeles), lymphoedema of the breast and elephantiasis of the legs were looked for. Few health centers were found in the study areas. The people were meant to gather at the nearest health centers that were nearer to them. The 'ogo' the common meeting place of the people were equally used.

The grading of lymphoedema was based on the WHO grading system of lymphoedema (Gerusa et al., 2002). Lymphoedema is graded in stages, ranging from stage 1 to stage 7.

\section{DIRECT SMEAR METHOD (WET PREPARATION)}

About $20 \mu \mathrm{l}(0.02 \mathrm{ml})$ of capillary blood collected with graduated pipette was mixed with 2 drops of water to lyze the red cells on a slide. The slide was covered with a cover slip and was examined for motile microfilariae using x10 objective. The direct smear method was used as a screening test for micofilariae, so it is not a sensitive test for microfilariae (Cheesbrough, 2002).

\section{COLLECTION OF BLOOD SAMPLES}

Blood samples were collected between the hours of $10.00 \mathrm{pm}$ and $1.00 \mathrm{am}$ from respondents who willingly reported at the medical centers of each village or the common meeting point of the people (ogo), which serve as the rallying points for each village. The microfilariae of $W$. bancrofti exhibits nocturnal periodicity and they are commonly found at the peripheral blood level during this time (10.00pm - 2.00am), (Cheesbrough, 2002; WHO, 2002). Collection of blood samples at this time also helped 
in detecting the microfilariae of $W$. bancrofti in blood (Cheesbrough, 2002; WHO, 2002).

Before collection of blood, hand gloves were worn to protect the researcher and the volunteers from contacting diseases or infections. Tourniquet was used in trying the arm to expose the vein, the area was cleaned using cotton wool soaked with methylated spirit (swab). About $2 \mathrm{mls}$ of venous blood was drawn from the arm using $2 \mathrm{ml}$ syringe and transferred into an EDTA bottle. The collected blood samples were used in testing for microfilariae of $W$. bancrofti using the wet preparation method, the Knott's concentration technique and the ICT method for testing for the circulating filarial antigen of W. bancrofti (Michael and Bundy, 1997).

\section{KNOTT'S CONCENTRATION TECHNIQUE}

$1 \mathrm{ml}$ of blood was mixed thoroughly with $9 \mathrm{ml}$ of $2 \%$ formalin in a centrifuge tube of about $15 \mathrm{ml}$. The contents were allowed to stand for 15 minutes before centrifugation at 2,000rpm for 5 minutes. The supernatant fluids were decanted and the sediment was used to make a thick film. The thick film was air-dried and stained with $3 \%$ Giemsa stain and left for about 30 minutes. The preparation was washed with distilled water and allowed to dry. The whole preparations were examined under low power (X40) of the microscope and also with oil immersion (x100) to detect the presence of microfilariae of W. bancrofti (Belding, 1965; Graig and Faust, 1970; Njenga and Wemae, 2001).

\section{METHOD OF ICT FILARIASIS TESTS (BINAX NOW FILARIASIS)}

The blood specimen was added to the pink test pad with batch no. PK300200, using 100ul capillary tube provided by the manufacturer. (Inverness Professional Diagnostic, Binax Inc. United States of America (U.S.A). Any W. bancrofti antigen present bounds to the colloid gold-labeled antibody. The card was closed accordingly. Antigen joined to the colloid gold-labeled antibody travelled up the strip. When the monoclonal antibody (MAB) line was reached, the antigen - antibody complex bound to the monoclonal antibody, and formed a pink line. A positive control was included which was seen as a pink line above the test card. The test was read within 5 minutes or 15 minutes for accurate results.

\section{LIMITATIONS OF THE ICT FILARIASIS TEST (BINAX NOW FILARIASIS)}

The test is structured to indicate the presence or absence of $W$. bancrofti antigen in the sample. The absence of antigen of $W$. brancrofti does not exclude filariasis caused by other nematodes species.

\section{STATISTICAL ANALYSIS}

Statistical Package for Social Sciences (SPSS) was used to test for the differences in the prevalence of infection using the wet preparation method, ICT and Knott's concentration method. It was also used to compare the prevalence between male and female subjects and between their ages. Tables were used to represent the frequency of occurrence of microfilariae in the study area and its percentage occurrence.

\section{RESULTS}

\section{PARASITOLOGICAL FINDINGS}

Out of 781 participants whose blood samples were examined for microfilariae, the results showed that Ezi Nwachi had the highest prevalence of $2(7.41 \%)$ and the highest microfilariae $(\mathrm{mf})$ density of $150 \mathrm{mf} / \mathrm{ml}$. The total microfilariae density using the wet preparation method is 750mf/ml (table1).

Table.1: Prevalence of lymphatic filariasis in Afikpo North using wet smear method

\begin{tabular}{|c|c|c|c|c|c|}
\hline Villages & Estimated & No Examined & No. Positive & \multicolumn{2}{|c|}{ MF density } \\
\hline & \multicolumn{2}{|c|}{ Population } & \multicolumn{2}{|c|}{ for $W . b$} & \\
\hline Ezi Egwu & 2000 & 25 & 1 & $(4.00)$ & 50 \\
\hline Kpogirikpo & 720 & 26 & 1 & $(3.85)$ & 100 \\
\hline Ukpa & 510 & 27 & 0 & $(0.00)$ & 0.00 \\
\hline Amachi & 290 & 24 & 0 & $(0.00)$ & 0 \\
\hline Mgbom & 420 & 26 & 0 & $(0.00)$ & 0 \\
\hline Ibii & 680 & 26 & 1 & $(3.85)$ & 50 \\
\hline Amangbala & 280 & 26 & 0 & $(0.00)$ & 0 \\
\hline Itim ukwu & 550 & 27 & 0 & $(0.00)$ & 0 \\
\hline Ezinnali & 220 & 26 & 1 & $(3.85)$ & 50 \\
\hline Ezinwachi & 100 & 27 & 2 & $(7.41)$ & 150 \\
\hline Amasiri & 750 & 26 & 1 & $(3.85)$ & 50 \\
\hline
\end{tabular}




\begin{tabular}{llllll}
\hline Ngodo & 120 & 26 & 0 & $(0.00)$ & 0 \\
Amachara & 150 & 26 & 0 & $(0.00)$ & 0 \\
Amuro & 110 & 26 & 1 & $(3.85)$ & 100 \\
Unwana & 840 & 26 & 1 & $(3.85)$ & 50 \\
Amaobolobo & 450 & 26 & 1 & $(3.85)$ & 50 \\
Enohia Nkalu & 140 & 26 & 0 & $(0.00)$ & 0 \\
Enohia Itim & 410 & 26 & 0 & $(0.00)$ & 0 \\
Amorie Ozizzia & 220 & 26 & 1 & $(3.85)$ & 50 \\
Amoha & 440 & 26 & 0 & $(0.00)$ & 0 \\
Amaizu & 320 & 26 & 0 & $(0.00)$ & 0 \\
Amauzu & 300 & 26 & 1 & $(3.85)$ & 0 \\
Amangwu & 350 & 26 & 0 & $(0.00)$ & 0 \\
Amaikpo Ozizza & 880 & 26 & 0 & $(0.00)$ & 0 \\
Ama Ukwu & 230 & 26 & 0 & $(0.00)$ & 0 \\
Amankwo & 365 & 26 & 0 & $(0.00)$ & 0 \\
Ugwuegu & 310 & 26 & 0 & $(3.85)$ & 50 \\
Akpoha & 430 & 26 & 1 & $(0.00)$ & 0 \\
Ezi Oti village & 210 & 26 & 0 & $(0.00)$ & 0 \\
Ezi Ogudu village & 180 & 27 & 0 & $(1.66 \%) 750$ &
\end{tabular}

NB: LF denotes $=$ Lymphatic filariasis; $W . b$

A total of 781 individuals were examined for circulating filarial antigen of Wuchereria bancrofti using the rapid immunochomatographic Test Cards (Binax Now Filarisis) (ICT) in thirty (30) villages of Afikpo North L.G.A., Ebonyi State, Nigeria, out of which 165 (21.13\%) were positive for ICT. Amuro village had the highest percentage prevalence of Wuchereria bancrofti antigen using the ICT method 9(34.61\%), table 2 .
$=$ Wuchereria bancrofti; $\mathrm{MF} \quad=$ Microfilaria

Table 2 also shows the prevalence of microfilariae of lympathatic filariasis using the Knott's concentration method. Here, 781 subjects were examined for microfilariae of lymphatic filariasis, 42(5.38\%) persons were positive. Ezinwachi village had the highest percentage prevalence of $14.81 \%$ microfilariae of Wuchereria bancrofti, and also with the highest percentage microfilariae density of $450 \mathrm{mf} / \mathrm{ml}$.

Table.2: Prevalence of lymphatic filariasis in Afikpo North LGA using ICT method and the knots concentration technique ICT method Knott's Concentration Technique

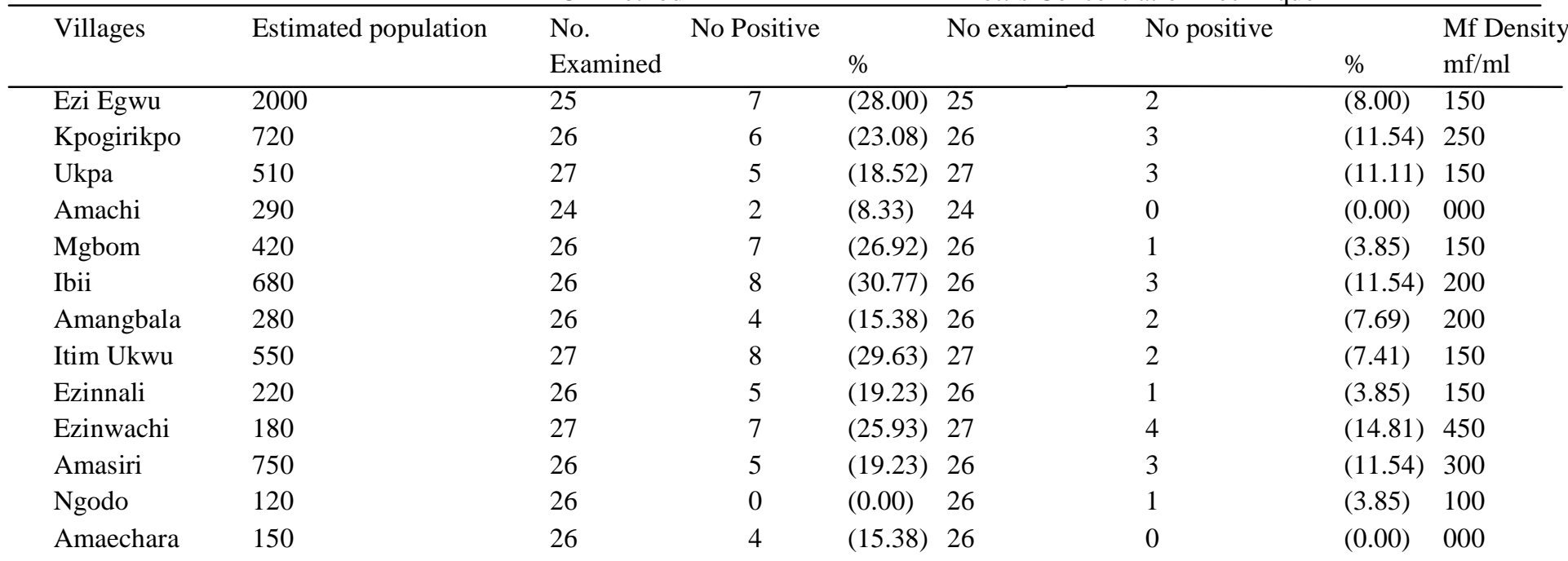




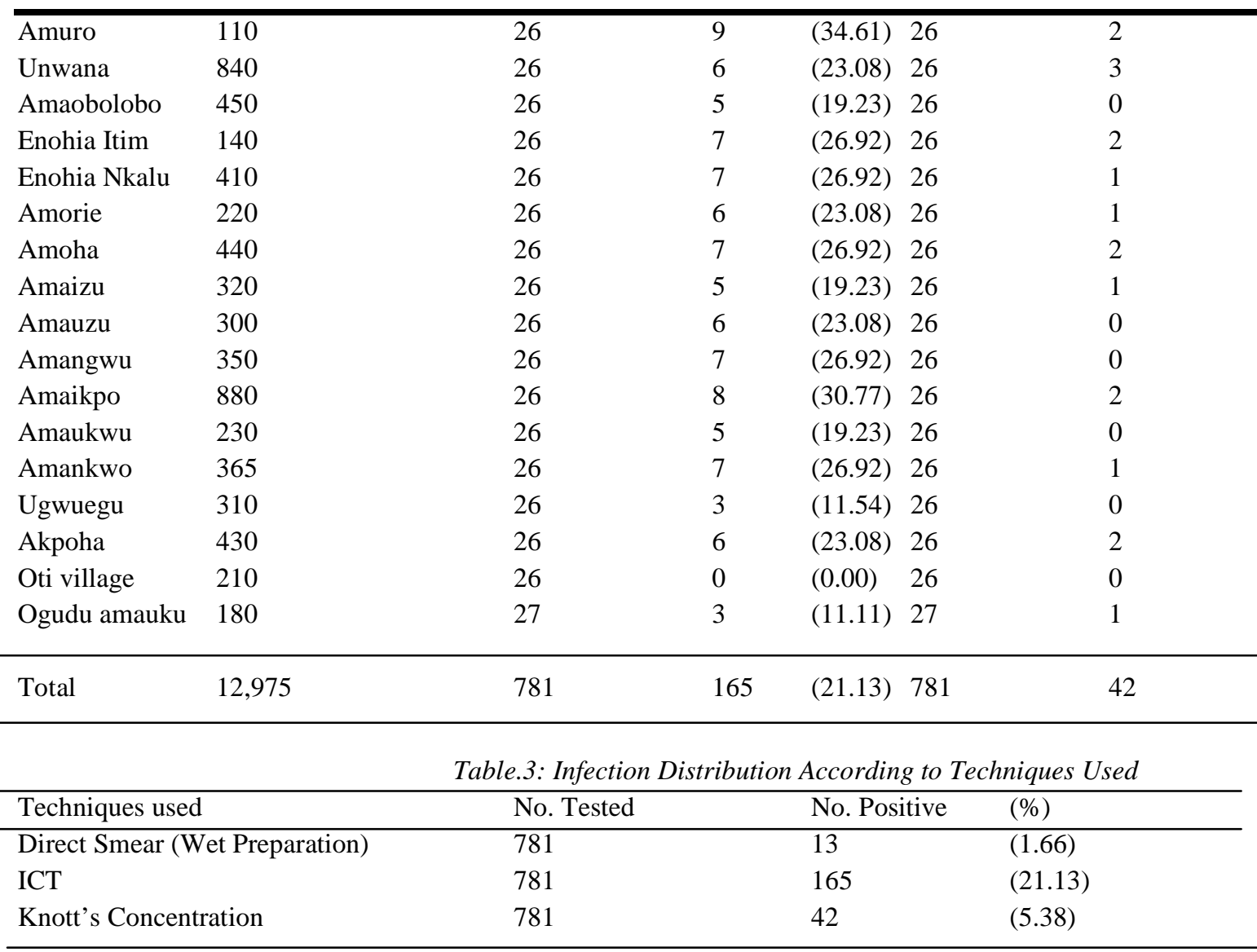

Table.4: Prevalence of Lymphatic Filariasis in Afikpo North Lga by Age and Sex Using ICT Method

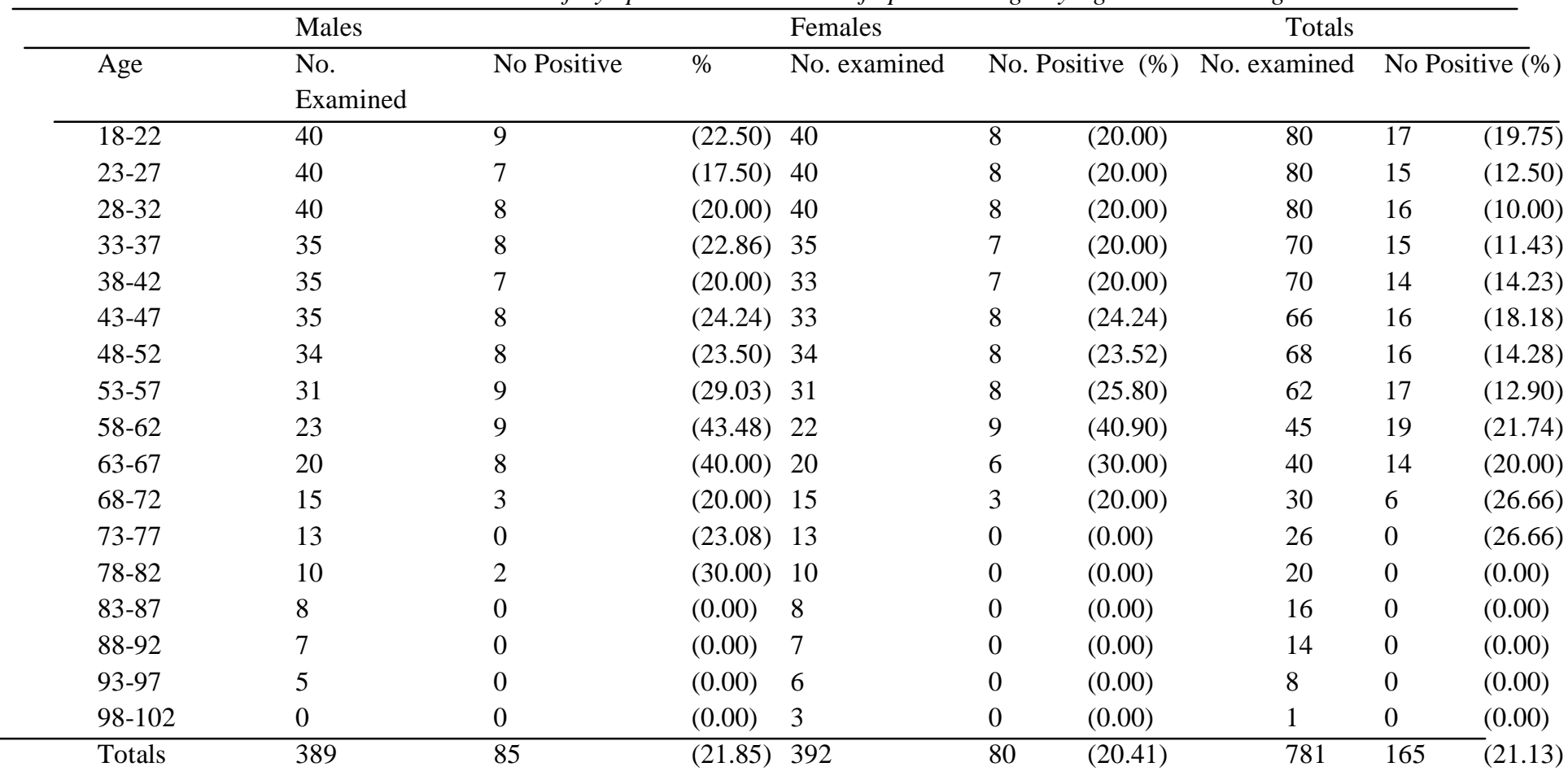


The prevalence of lymphatic filariasis in Afikpo North L.G.A., by age and sex, using ICT method, is shown in Table 4. A total of $85(21.85 \%)$ males were positive for circulating filarial antigen of $W$. bancrofti. Out of 389 males examined using the ICT method, subjects within the age group 58-62 years had the highest percentage prevalence of $43.48 \%$. Out of 392 females examined using the ICT method, only $80(20.41 \%)$ of the subjects were positive. Females within the age group 58-62 years had the highest percentage prevalence of $40.90 \%$. The prevalence of infection using ICT card in both sexes and of different age groups is $21.13 \%$. Males were more infected $(21.85 \%)$ than females $(20.41 \%)$. However, there is no significant difference between sexes (males and females), using the ICT cards $(\mathrm{p}>0.05)$.

Table.5: Prevalence of lymphatic filariasis in Afikpo North LGA by age and sex using the Knott's Concentration Technique Males

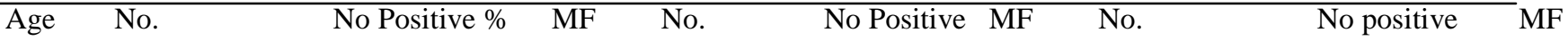

Group examined Density examined $\% \quad$ density examined $\%$ density

\begin{tabular}{|c|c|c|c|c|c|c|c|c|c|c|c|c|}
\hline $18-22$ & 40 & 1 & $(2.50)$ & 150 & 40 & 2 & $(5.00)$ & 100 & 80 & 3 & $(7.50)$ & 250 \\
\hline $23-27$ & 40 & 1 & $(2.50)$ & 100 & 40 & 2 & $(5.00)$ & 100 & 80 & 3 & $(7.50)$ & 200 \\
\hline $28-32$ & 40 & 2 & $(5.00)$ & 200 & 40 & 1 & $(2.50)$ & 50 & 80 & 3 & $(7.50)$ & 250 \\
\hline $33-37$ & 35 & 1 & $(2.86)$ & 50 & 35 & 1 & $(2.86)$ & 50 & 70 & 2 & $(5.86)$ & 100 \\
\hline $38-42$ & 35 & 2 & $(5.71)$ & 150 & 35 & 1 & $(2.86)$ & 100 & 70 & 3 & $(8.57)$ & 250 \\
\hline $43-47$ & 33 & 3 & $(9.09)$ & 450 & 33 & 1 & $(3.03)$ & 100 & 66 & 4 & (12.12) & 550 \\
\hline $48-52$ & 34 & 3 & $(8.82)$ & 350 & 34 & 2 & $(5.88)$ & 150 & 68 & 5 & (14.70) & 500 \\
\hline $53-57$ & 31 & 4 & (12.90) & 550 & 31 & 3 & $(9.68)$ & 350 & 62 & 7 & $(22.58)$ & 900 \\
\hline $58-62$ & 23 & 6 & (26.09) & 750 & 22 & 4 & (18.18) & 450 & 45 & 10 & $(44.70)$ & 1200 \\
\hline $63-67$ & 20 & 1 & $(5.00)$ & 100 & 20 & 1 & $(5.00)$ & 150 & 40 & 2 & $(10.00)$ & 250 \\
\hline $68-72$ & 15 & 0 & $(0.00)$ & 000 & 15 & 0 & $(0.00)$ & 000 & 30 & 0 & $(0.00)$ & 000 \\
\hline $73-77$ & 13 & 0 & $(0.00)$ & 000 & 13 & 0 & $(0.00)$ & 000 & 26 & 0 & $(0.00)$ & 000 \\
\hline $78-82$ & 10 & 0 & $(0.00)$ & 000 & 10 & 0 & $(0.00)$ & 000 & 20 & 0 & $(0.00)$ & 000 \\
\hline $83-87$ & 8 & 0 & $(0.00)$ & 000 & 8 & 0 & $(0.00)$ & 000 & 16 & 0 & $(0.00)$ & 000 \\
\hline $88-92$ & 7 & 0 & $(0.00)$ & 000 & 7 & 0 & $(0.00)$ & 000 & 14 & 0 & $(0.00)$ & 000 \\
\hline $93-97$ & 5 & 0 & $(0.00)$ & 000 & 6 & 0 & $(0.00)$ & 000 & 1 & 0 & $(0.00)$ & 000 \\
\hline $98-102$ & 0 & 0 & $(0.00)$ & 000 & 3 & 0 & $(0.00)$ & 000 & 3 & 0 & $(0.00)$ & 000 \\
\hline Total & 389 & 24 & $(6.16)$ & 2850 & 392 & 18 & $(4.59)$ & 1600 & 781 & 42 & $(4.38 \%)$ & 4450 \\
\hline
\end{tabular}

Table 5 shows the prevalence of lymphatic filariasis in Afikpo North L.G.A. by age and sex, using the Knott's concentration Techniques. Three hundred and eighty nine (389) males were examined using Knott's Concentration Technique, 24(6.16\%) were positive. Individuals within the age brackets 58-62 years had the highest percentage prevalence of $18.18 \%$, males were more infected than females $(\mathrm{p}>0.05)$, there is no significant difference between sexes (males/females).

The microfilariae density of males was $2850 \mathrm{mf} / \mathrm{ml}$, while females had $1600 \mathrm{mf} / \mathrm{ml}$. Then the total microfilariae density was found to be $4450 \mathrm{mf} / \mathrm{ml}$, using the Knott's Concentration Techniques. Males had higher microfilariae density $(2850 \mathrm{mf} / \mathrm{ml})$ than females $(1600 \mathrm{mf} / \mathrm{ml})$.

Table.6: Sizes of hydrocoeles found in Afikpo North L.G.A.

\begin{tabular}{ccccccc} 
Villages & Age & No. & No. positive (\%) & Occupation & Sizes of hydrocoeles in \\
\hline & \multicolumn{3}{c}{ Range } & examined & & cm per positive case \\
Amaizu & $73-77$ & 13 & 2 & $(15.38)$ & farmers & 25,23 \\
Amaizu & $53-57$ & 40 & 2 & $(5.00)$ & farmers & 18,20 \\
Unwana & $43-47$ & 33 & 3 & $(9.09)$ & traders & $18,20,21$ \\
Unwana & $48-52$ & 34 & 3 & $(8.84)$ & traders & $18,20,21$
\end{tabular}




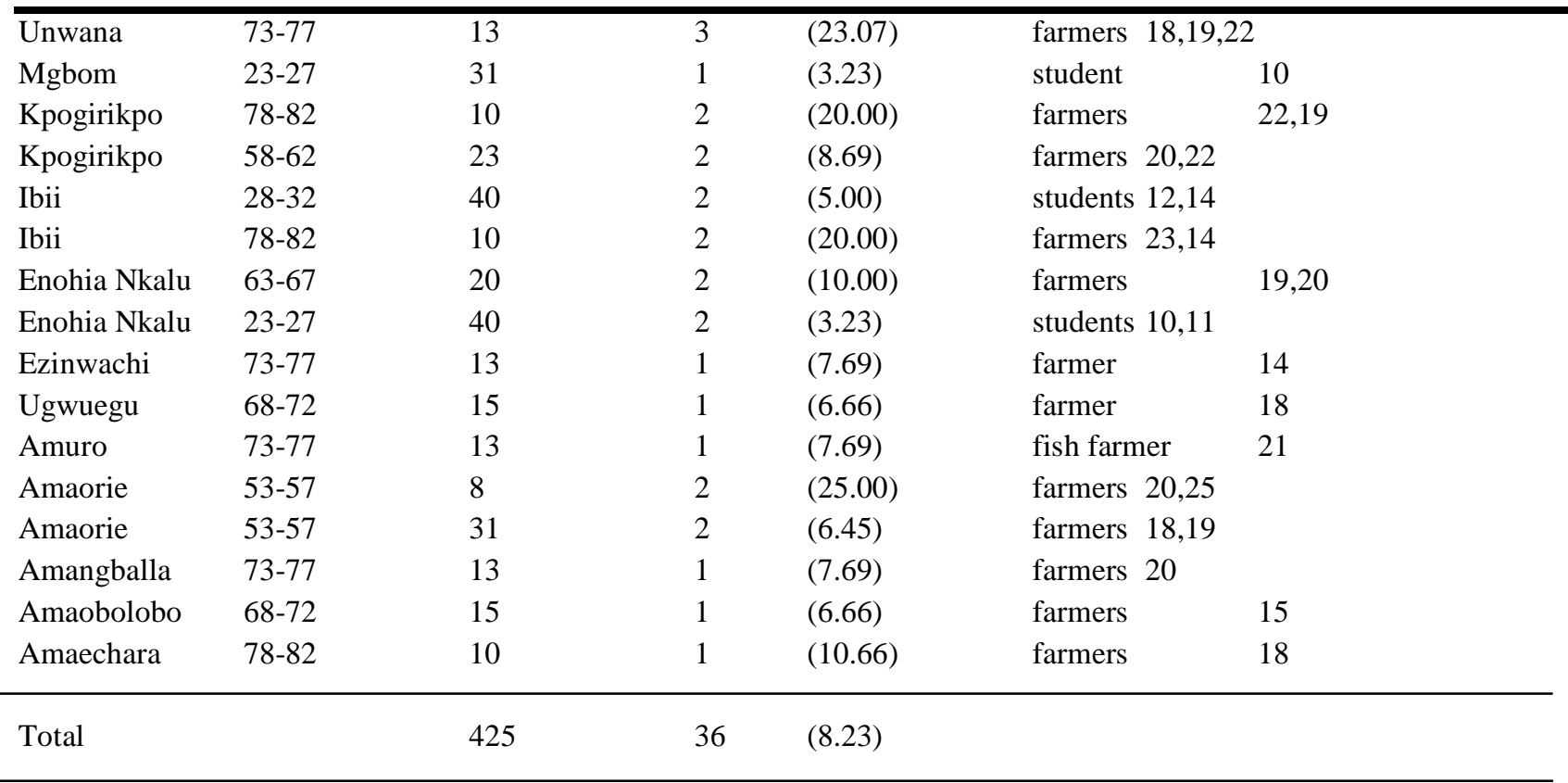

Table 6: shows sizes of hydrocoeles fond in Afikpo North L.G.A., according to village, age range and occupation. Unwana village had the highest number of subjects with hydrocoeles. They were nine (9) positive cases of hydrocoeles ranging from $18 \mathrm{~cm}-22 \mathrm{~cm}$. Hydrocoeles found from the study areas ranges from $10 \mathrm{~cm}-25 \mathrm{~cm}$ in size. Hydrocoeles affect subjects of different occupations. Hydrocoeles affect the older people more than the younger people. Subjects within the age brackets $83-87$ years had the highest percentage prevalence $(25.00 \%)$ while subjects within the age group 23-27 years had the lowest percentage prevalence $(3.23 \%)$. Overall prevalence of hydrocoeles was $(8.23 \%)$. Also fig. 1 shows the pie chart representing the percentage positive of hydrocoeles found in Afikpo North L.G.A. Hydrocoele affects subjects of different age groups.

Table.7: Lymphoedema and their different stages observed in Afikpo North LGA among both sexes.

\begin{tabular}{|c|c|c|c|c|c|c|c|c|c|}
\hline Village & $\begin{array}{l}\text { Age } \\
\text { range }\end{array}$ & $\begin{array}{l}\text { No. } \\
\text { examined }\end{array}$ & $\begin{array}{l}\text { No } \\
\text { positive }\end{array}$ & Occupation & $\begin{array}{r}\text { No. } \\
\text { po }\end{array}$ & & positive & $\begin{array}{l}\text { No of females } \\
\%\end{array}$ & Stage \\
\hline Unwana & $78-82$ & 10 & 2 & farmer & 0 & $(00)$ & 2 & $(20.00)$ & 3.2 \\
\hline Unwana & $73-77$ & 13 & 2 & farmer & 1 & $(7.69)$ & 1 & $(7.69)$ & 3.4 \\
\hline Mgbom & $78-82$ & 10 & 1 & fish farmer & 1 & $(10.00)$ & 0 & $(0.00)$ & 3 \\
\hline Kpogirikpo & $73-77$ & 13 & 1 & farmer & 1 & $(7.69)$ & 0 & $(0.00)$ & 3 \\
\hline Amaizu & $73-77$ & 13 & 1 & farmer & 1 & (7.69) & 0 & $(0.00)$ & 4 \\
\hline Amangballa & $53-57$ & 31 & 1 & trader & 1 & $(3.23)$ & 3 & $(0.00)$ & \\
\hline Total & & 90 & $8(8.88)$ & & 5 & $(5.55)$ & 3 & (3.33 & \\
\hline
\end{tabular}

Table 7 shows the different stages of lymphoedema found in Afikpo North L.G.A., among both sexes. Eight positive cases of hymphoedema were observed in Afikpo North L.G.A. Unwana village had the highest cases (4 positive cases). The individuals were mainly subjects from 53 years and above they were mainly farmers. Males were more affected with lymphoedema than females. There were five positive cases of males while females had three positive cases. The stages of hymphoedema ranged from stage three (3) to stage four (4). Subjects within the age group 78-82 years females had the highest prevalence $20.00 \%$, while subjects within the age brackets 53-57 years males had the least prevalence $3.22 \%$. However, no positive case was recorded among females within the same age group (53-57 years). Males generally had a higher prevalence of $5.55 \%$ while females had a lower prevalence of $3.33 \%$. Overall 
prevalence of lympoedema of $8.88 \%$ was recorded in both

V.

\section{DISCUSSION, SUMMARY AND CONCLUSION}

\section{DISCUSSION}

\section{PREVALENCE}

The results of this research show that lymphatic filariasis which is caused by $W$. bancrofti exists in Afikpo North LGA, Ebonyi State, Nigeria. The under listed prevalences were observed. The direct smear method which is a non sensitive test for lymphatic filariasis had a prevalence of $1.66 \%$, while the Knott's concentration method which is a more sensitive test for detecting $W$. bancrofti in blood had a prevalence of $5.38 \%$. The immunochromatographic (ICT) test method which dictates the circulating filarial antigen of $W$. Bancrofti had a prevalence of $21.13 \%$.

Ibanga (2004), in her work at Obanlinku, Cross River State recorded a prevalence of $1.00 \%$ for lymphatic filariasis using the thick blood smear method. The low prevalence was as a result of ivermectin distribution among the populace before carrying out the parasitological test. Udonsi and Odey (1985), Udonsi (1986 and 1988) established a prevalence of $8.7 \%$ in Yala, Cross River State, $25.6 \%$ in the Niger Delta and $12.8 \%$ in Igwun River Basin, Abia State. Targema et al., (2007) had a related finding of $6.50 \%$ in comparism with the prevalence of $5.38 \%$ established in this work using the same method of Knott's Concentration technique. There has never been mass treatment of ivermectin or in a combination of ivermectin and albendozole in the treatment of lymphatic filariasis in Afikpo North LGA. This gives rise to the high prevalence of 5.38\%. Mbah and Njoku (2000) in their work, in Oraeri, Aguata, LGA., Anambra State observed a higher prevalence rate of $18.80 \%$. Njenga et al., (2008) recorded a prevalence of $7.10 \%$ in their works in Malindi Kenya.

In a work carried out by Njenga and Wamae (2001) in Nairobi, Kenya, they established a higher prevalence rate of $37.3 \%$ of lymphatic filariasis, using the ICT method, as against $21.13 \%$ recorded in this work, using the ICT method also.

Eigege et al., (2002) reported a similar prevalence rate of $22.6 \%$ using the ICT method in Lafia, Nasarawa State, Nigeria, just as established in this work $21.13 \%$ in Afikpo North L.G.A. Ebonyi State.

A microfilariae density of $1 \mathrm{mf} / 50 \mu \mathrm{l}$ to $7 \mathrm{mf} / 50 \mu \mathrm{l}$ was equally observed in the study using the Knott's concentration Technique. Ibanga, (2004) noted a similar report in Obanliku, Cross River State, Nigeria. Ngenga and Waemae (2001) carried out a research using the immunochromatographic technique (ICT) and recorded a prevalence of $21.60 \%$ in Kenya, which is close to the sexes in Afikpo North LGA.

$21.13 \%$ recorded in this work, using immunochromatographic technique.

The prevalence of lymphatic filariasis was found to be higher in males $(21.85 \%)$ than in females $(20.41 \%)$ using the ICT method. Also, with the Knott's Concentration Technique, prevalence was equally higher in males $(6.16 \%)$ than in females $(4.59 \%)$. There was no statistically significant difference between both sexes in terms of prevalence using both methods ( $>0.05)$, at two tailed significance difference of .780 .

Ibanga (2004) observed higher prevalence in females $(1.40 \%)$ than in males $(0.55 \%)$. Gyapong et al., (1994) also observed higher prevalence of lymphatic filariasis in females $(18.6 \%)$ than in males $(15.8 \%)$.

Badaki et al., (1999) equally observed higher prevalence of Wuchereria bancrofti microfilariae in males $(19.56 \%)$ than in females (18.42\%). Mba and Njoku (2000) in Aguata LGA, of Anambra State, Nigeria, established that males had more prevalence of Wuchereria bancrofti microfilariae $(24.5 \%)$ than the females $(23.01 \%)$, and reported that there was no significant difference between both sexes. (Ngele and Osonwa, 2010) also reported that males were more infected with the microfilariae of $W$. bancrofti than females from their research work carried out in Ofumbonga Communities Obubra, Cross River State, Nigeria.

In the majority of villages visited in Afikpo North LGA, it was observed that men were mostly found outdoors gathering at the "Ogo" telling stories even at late hours of the night. This act of sitting outside at late hours of the night when the microfilariae of $W$. bancrofti are commonly found at the peripheral blood level encourages the transmission of microfilariae of $W$. bancrofti by mosquito vectors, which show nocturnal periodicity in their biting habits. The female at this time are mostly indoors, where the biting rates of the mosquito vectors are less. The males are also engaged with different clandestine activities like 'obon' 'Akang' etc that last into the night which do not involve the women. The males equally are involved in night hunting which also predisposed them to the mosquito vectors of $W$. bancrofti. Most of the houses visited had no mosquito nets, were not sealed with ceiling, while insecticide are not used in killing mosquitoes. These create entrance for the mosquito vectors of $W$. bancrofti into the houses. The same observations were made by Mba and Njoku (2000) and Ibenga, (2004). The prevalence of circulating filarial antigen, using ICT method, with age shows that subjects within the age group 58-62 years had the highest prevalence of $43.48 \%$ for males while $40.90 \%$ for females. Subjects within 73 years and above had no

Page | 948 
circulating filarial antigen of $W$. bancrofti in their blood. Eigege et al., (2002) had a similar result in Lafia, Nasarawa State, Nigeria.

Also the prevalence of $W$. bancrofti microfilariae using the Knott's Concentration Techniques shows that subject within the age group 58-62 years had the highest percentage prevalence of $26.09 \%$ for male and $18.18 \%$ for females. Subjects from 68 years and above had no microfilariae in their blood. Badaki et al., (1999) found the highest prevalence of microfilariae of lymphatic filariasis in the age group of individuals older than 50 years and above but lowest in individuals within $10-19$ years of age. Mbah and Njoku (2000) found the highest prevalence within the age group $31-60$ years and subjects below the age of 10 years and subjects with 70 years and above had no microfilariae in their blood. This prevalence of infection with age suggests that, infection is acquired early in life and builds up in the lymphatic vessels as the person grows older in age. The absence of circulating filarial antigen and the microfilarial in the blood of subjects above 73 years and 68 years respectively, using ICT and Knotts concentration methods, may be due to acquired immunity after many years of exposure and death of the adult worms in the body after living for about 10-15 years and above (Adams and Maegraith, 1978). It could also be as a result of inability of new infection to be established due to acquired immunity (Adams and Maegraith, 1978; WHO 2002).

Mass treatment of the people with mectizan or ivermectin alone or a combination of mectizan and albendazole, or with diethylcarbamazine (DEC) has not been organized in Afikpo North LGA, and this may be the reason why prevalence rates of $21.13 \%$ and $5.38 \%$ using the ICT and Knott's concentration techniques respectively were recorded in the area. Some individuals who are close to the local government headquarters collect their drugs (mectizan) direct from there where they are commonly deposited. Those who are far from the headquarters cannot access the drug (mectizan). Very few health facilities were found to be distributing the drug in the area and a few people also come around to collect the drug due to lack of awareness.

Ottesen et al., (1997) suggested that mectizan administered annually could result in up to $90 \%$ reduction in microfilarial load, which can interrupt the transmission. Bockarie et al., (1998) also suggested that a reduction in the microfilarial reservoir (human infected with microfilariae) by mass chemotherapy may interrupt transmission and thereby eliminate the infection. They observed decrease in microfilarial rate, density and annual transmission potential just after one year of treatment. Ngele and Oparaocha
(2007), recorded $90 \%$ clearance of microfilariae of $W$. bancrofti, using a combination of ivermectin and albendazole in the treating the people of Ofumbonga no 1-4 Obura LGA, Cross River State, Nigeria for a period o one year. Eigege et al., (2002) also reported a general reduction in infection rates in mosquitoes $15.0 \%$ to $3.3 \%$ to $2.6 \%$ respectively with only 3 years of treatment in Plateau and Nasarawa States, Nigeria. If the individuals harbouring the microfilariae are treated, this will help to reduce the transmission rate, vector infection and infectivity rates.

The farming practices of the people predispose them to the vector bites of $W$. bancrofti all year round. The Afikpo people are predominantly farmers; they cultivate rice, yam, and maize among other crops twice in a year (May/June and August/September). Another reason for the high level of prevalence of $W$. bancrofti is their level of income. Majority of Afikpo people are living beyond average level. Most people in Afikpo have inadequate housing, greater exposure to infected mosquitoes, limited access to health centers and lack of adequate awareness. The disease lymphatic filariasis had been described by WHO (1997) as a disease of the poor. Similarly, (Coriel et al., 2003) have reported poverty and poor living conditions as the fundamental causes of persistence lymphatic filariasis in Haiti. That is why the disease is commonly found among the low income earners in the society.

\section{CLINICAL MANIFESTATION}

Hydrocoeles (8.23\%) were observed in Afikpo North L.G.A., the presence of hydrocoele cuts across subjects of different age groups. Subjects within the age bracket 83-87 years had the highest prevalence of $25.00 \%$, while subjects within the age brackets 23-27 years had the least prevalence of hydrocoeles $(3.23 \%)$ amongst the positive cases. The sizes of the hydrocoeles differ within the age groups. Subjects within the age bracket 83-87 years had bigger sizes of hydrocoeles $25 \mathrm{~cm}$ at maximum while subjects within the age bracket 23-27 years had less sizes of hydrocoeles of $10 \mathrm{~cm}$, who were invariably younger. Dunyo et al., (1999) established a higher prevalence of $21.85 \%$ in Pemba Island, Tanzania. Onapa et al., (2001) working in Uganda; Udonsi and Odey (1985) working Niger Delta Regions of Nigeria also established higher prevalence of Hydrocoeles of $28.0 \%$ and $17.8 \%$ respectively. Udonsi (1986 and 1988) also recorded a prevalence of $12.7 \%$ hydrocoeles among adult males in Igwun River Basin of Abia State, Nigeria. Ufomadu and Ekejindu (1992) and Targema et al., (2008) recorded lower hydrocoeles prevalence of $1.8 \%$ and $2.3 \%$ in plateau and Benue States, Nigeria respectively. Poverty is a major handicap in Afikpo North LGA, so the people find it difficult to go to hospital for surgical operation owing to the

Page | 949 
high cost of money involved in the surgical operation of the hydrocoeles.

Eigege et al., (2002) established a hydrocoele prevalence of $12.2 \%$ and $13.3 \%$ in Plateau and Nasarawa States respectively. Ibanga (2002) found low hydrocoele prevalence of $0.74 \%$ in Obanliku, Cross River State, Nigeria.

A prevalence of $8.88 \%$ lymphoedema was found in Afikpo North L.G.A. Pendersen et al., (1999) recorded lower prevalence of $1.4 \%$ lymphoedema (elephantiasis) in Pemba Island, Tanzania. Dunyo et al., (1996); Onapa et al. (2001) had similar findings of $8.6 \%, 9.0 \%$ prevalence of lymphoedema in Ghana and Uganda respectively, which is similar to the $8.88 \%$ prevalence of lymphoedema established in Afikpo North L.G.A., Ebonyi State, Nigeria. Udonsi (1986) recorded a higher prevalence of $15.9 \%$ in Igwun River Basin of Abia State, Nigeria. Low level of income among the people and also constant exposure to the bite of infected mosquito vectors contributed to the high prevalence of lymphoedema in Afikpo North L.G.A.

\section{SUMMARY AND CONCLUSION}

The following prevalence were obtained using the following parasitological methods; the Wet Smear Preparation 1.66\% Knott's Concentration technique $5.38 \%$ and the immune chromatographic technique (ICT) $21.13 \%$.

Males were more infected with Wuchereria bancrofti than females. Subjects within the age bracket 58-62 years both males and females had the highest percentage prevalence of $W$. bancrofti. Hydrocoeles were equally observed among subjects in Afikpo North LGA. Unwana village had the highest number of subjects with hydroceoles. with hydrocoeles. Hydrocoele sizes ranges from $10 \mathrm{~cm}-25 \mathrm{~cm}$.

Different stages of lymphoedema were equally observed in Afikpo North LGA. Eight positive cases were observed and recorded. Males were more affected than females. Prevalence of lymphoedema was highest among subjects within the age bracket $78-82$ years, $20.00 \%$ while subjects within 53-57 years had the least prevalence of hydrocoeles $3.22 \%$.

\section{RECOMMENDATIONS}

The following recommendations are made;

1. Afikpo North LGA should be included in the list and map of WHO, as one of the areas for the control and elimination of lymphatic filariasis in line with the WHO resolution of eliminating lymphatic filariasis by the year 2020 .

2. Health education methods (awareness campaign programme) should be developed which can help to break through the walls of suspicion and supernatural beliefs from locality to locality, on the cause of lymphatic filariasis, if prevention and control programmes are to make any impact in the rural areas.

3. There should be mass treatment of the people using the combination therapy of albendazole and mectizan.

4. The people should be encouraged to use insecticide treated nets, ordinary nets and insecticide in controlling the mosquito vectors.

5. General cleanliness of their environments should be encouraged to destroy the breeding sites of the mosquito vectors. That is, by cutting down grasses around them, and by destroying stagnant water around their environment. Integrated control method is highly recommended, if employed, will yield good result.

\section{REFERENCES}

[1] Badaki, J. A., Akogun, O. B. and Akoh, J. I. (1999). The effect of low dose of ivermectin in the treatment of Wuchereria bancrofti in diurnal blood. The Nigeria Journal of Parasitology. 20: 83-89.

[2] Belding, D. L. (1965). Textbook of Parasitology. $3^{\text {rd }}$ ed. Appleton-Century crofts. Division of Menedith Publishing Company: New York PP. 1374.

[3] Cheesbrough, M. (2002). District Laboratory Practice in Tropical Countries part 1. Published by Cambridge University Press, United Kingdom. 453pp.

[4] Dunyo, S. K., Appawu, M., Nkurumah, F. K., Baffoe, W. A., Pederson, E. M, and Simonsen, P. E. (1996). Lymphatic filariasison the coast of Ghana. Transactions of the Royal Society of Tropical Medicine and Hygiene. 90: 634-638.

[5] Eigege, A., Frank, O. R., Blanney, D. D., Miri, E. S.,Gontor, I., Ogah, G., Umaru, J., Jinadu, M. Y., Mathal, W. A., Amadiegwu, S. and Hopkins, D.R. (2002). Rapid assessment for lymphatic filariasis in Central Nigeria; A comparism of the immunochromatographictest cards and Hydrocoel rates in an area of high endemicity. American Journal of Tropical Medicine and Hygiene. 68: 643-646.

[6] Hunter, G. W., Swartzwelder, J. C. and David, F. C. (1976). Tropical Medicine. Pnublished by W. B. Saunders Company, Philadelphia, USA, fifth edition. 900pp.

[7] Ibanga, N. J. (2004). Epidemiology of lymphatic filariasis in Obanliku LGA, Cross River State, Nigeria. Ph.D Thesis submitted to the Department of Zoology, University of Calabar, Cross River State, Nigeria.

[8] Iloeje, P. U. (1981). Regional Geography for West Africa. $2^{\text {nd }}$ Ed. Macmillan Publishers, Nigeria. 240pp.

[9] Mbah, D. C. \& Njoku O. O. (2000). Prevalence of lymphatic filariasis (LF) in Orari Aguato Local 
Government Area of Anambra State, Nigeria. The Nigerian Journal of Parasitology. 21: 95-102.

[10] Michael, E., \& Bundy, D.A.P. (1997). Re-assessing the Global mapping of lymphatic filariasis. Parasitology today. 13: 472 - 476.

[11]National Population Commission (NPC) (2000). Census and demographic Report of Nigeria. Published by the Nigerian Minting and Printing Press Abuja Nigeria. 18-45.

[12] Ngele, K.K. and Oparaocha, E. (2007). The combined effects of albendazole and mectizan (ivermectin) in the treatment of lymphatic filariasis: A case study of four rural Communities in Obubra LGA, Cross River State, Nigeria. The Global Journal of Medical Sciences 6 (2): $73-80$

[13] Ngele, K.K. and Osonwa E. (2010). Prevalence of lymphatic filariasis among adults in Ofumbongha Communities in Obubra LGA, Cross River State, Nigeria. Nigerian Journal of Pharmaceutical Research 8 (1): 58-161.

[14] Njenga, S. M. \& Wamae, C. N. (2001). Evaluation of ICT Filariasis card test using whole capillary Blood; comparison with Knott's Concentration and Counting Chamber Methods. Centre for Microbiology Research, Kenya Medical Research Institute Nairobi. 72: 150180.

[15] Ottesen, E. A. and Ramachandran, C. P. (1995). Lymphatic Filariasis Infection and Disease: Control Strategies. Parasitology Today. 11, 129 - 131.

[16] Ottensen, E. A. Ismail, M. M. and Horton, J. (1999). The Role of Albendazole in Programme to Eliminate Lymphatic Filariasis. Parasitology Today. 15, 382 386.

[17] Ottensen, E. A. Skvaril, C. K., \& Tripathy, S. P. (1985). Prominence of $\operatorname{lgG} 4$ in $\operatorname{lgG}$ antibody response to human filariasis. Journal of Immunology. 134: 2707 $-2713$.

[18] Ottesen, E. A. (1994). The human filariasis: New understanding, New therapeutic Strategies. Current opinions in infectious diseases. 7: 550 - 558.

[19] Ottesen, E. A. (2000). The Global Programme to Eliminate Lymphatic filariasis. Tropical Medicine and International Health. 5, 591 - 594.

[20] Ottesen E. A., Duke, B. O. L. Karem, M., \& Belibehani, K. (1997). Strategies and tools for the control/elimination of lymphatic filariasis. Bulletin of the world health Organization. 75: 491 - 503.

[21] Service, M. W. (1993). Mosquito Ecology: Field Sampling Methods. ( $2^{\text {nd }}$ Edition), London. The Macmilan Press 241pp.
[22] World Health Organization (1994). Lymphatic filariasis infection and disease control strategies, report of a consultative meeting held at the University Stains, Malaysia, Penang, Malasia. World Health Organization, Geneva $52-68$.

[23] World Health Organization (2002). Situation Analysis for a multi-country study on management of lymphoedema and acute adenolymphangitis in Africa UNDP/World bank/WHO Special Programme for Research and Training in Tropical Diseases 18-28.

[24] World Health Organization CD - ROM (2003). The Elimination of Lymphatic Filariasis. An interactive guide for programme managers, Geneva. $92-120$. 